\title{
Regulation of $A_{1}$ Adenosine Receptors by Amiodarone and Electrical Stimulation in Rat Myocardial Cells In Vitro
}

\author{
Dalia El-Ani ${ }^{*}$, Kenneth A. Jacobson ${ }^{\dagger}$, and Asher Shainberg ${ }^{*}, \neq$ \\ *The Otto Meyerhoff Drug Receptor Center, Department of Life Sciences, Bar-Ilan University, \\ Ramat-Gan 52900, Israel \\ †Molecular Recognition Section, Laboratory of Bioorganic Chemistry, NIH, NIDDK, Bethesda, MD \\ 20892, U.S.A
}

\begin{abstract}
The effects of conditions that either increase or decrease heart rate on the pharmacological properties of adenosine receptors in cultured rat myocytes were examined. Levels of $A_{1}$ adenosine receptors, following prolonged treatment with electrical stimulation (ES) or the antiarrhythmic drug amiodarone, were determined using radioligand binding with the specific $\mathrm{A}_{1}$ receptor antagonist $\left[{ }^{3} \mathrm{H}\right] 1$,3-dipropyl-8-cyclopentylxanthine (CPX). The effects of lowering temperature were also explored. Exposure to amiodarone for 4 days reduced the density of $\mathrm{A}_{1}$ receptors by $19 \%$ (from $24.7 \pm 0.4$ to $20.09 \pm 0.3 \mathrm{fmol} / \mathrm{dish}$ ) and inhibited the rate of contraction by $60 \%$ (from $188 \pm 16$ to $76 \pm 30$ beats $/ \mathrm{min}$ ), without changing the receptor affinity, protein content, creatine kinase (CK) activity or cell number. Electrical stimulation at $25^{\circ} \mathrm{C}$ elevated the density of $\mathrm{A}_{1}$ adenosine receptors by $185 \%$ (from $4.1 \pm 0.4$ to $11.69 \pm 2.1 \mathrm{fmol} / \mathrm{dish}$ ). Four days of reduced temperature (from $37^{\circ} \mathrm{C}$ to either 30 or $25^{\circ} \mathrm{C}$ ) lowered the density of $\mathrm{A}_{1}$ adenosine receptors by 69 or $86 \%$, respectively (from $24.1 \pm 1.2$ to $7.4 \pm 0.4$ or $3.4 \pm 0.3 \mathrm{fmol} / \mathrm{dish}$ ), with no significant change in the receptor affinity, activity of CK, or lactate dehydrogenase (LDH), protein content or cell number. The observed up- and down-regulation of $\mathrm{A}_{1}$ adenosine receptors in primary myocyte cultures in response to conditions that exogenously alter the rate of contraction, is indicative of the role of adenosine receptors in adaptation of heart cells to stress.
\end{abstract}

\section{Keywords}

adenosine receptor; heart rate; amiodarone; electrical stimulation; temperature; cardiocytes

\begin{abstract}
Adenosine and amiodarone are antiarrhythmic agents that slow conduction, suppress premature heart beats, are used for the emergency treatment of supraventricular tachycardia [1-3], and are used for long-term treatment of atrioventricular tachycardia [4]. Both drugs decrease heart rate as a result of direct effects on the sinoatrial (SA)§ node [5, 6].

The $A_{1}$ adenosine receptor is upregulated in hyperthyroidism [7], an effect accompanied by stimulation of myocardial contractility and a biochemical transition of slow- twitch ("red")
\end{abstract}

\footnotetext{
${ }^{\ddagger}$ Corresponding author: Prof. Asher Shainberg, Department of Life Sciences, Bar-Ilan University, Ramat-Gan 52900, Israel. TEL: 972-3- 5318265; FAX: 972-3-5351824; shaina@ ashur.cc.biu.ac.il.
} 
muscle to the fast-twitch ("white") muscle type [8]. Treatment with amiodarone, which bears a structural similarity to thyroxin, decreased the serum level of $\mathrm{T}_{3}[9]$ and caused similar symptoms of hypothyroidism [10]. Amiodarone decreased sensitivity of the heart to catecholamines via a noncompetitive inhibition of catecholamine receptors and decreased the number of $\beta$-adrenoceptors in the myocardium $[10,11]$.

Electrical stimulation (ES) inhibited the synthesis of nicotinic acetylcholine receptors [12] and increased the density of L-type $\mathrm{Ca}^{2+}$ channels [13] in cultured muscle cells. ES also reduced the levels of muscarinic acetylcholine receptors [14] in myocardial cells in vitro.

In the present study we have examined the effects of conditions that either increase or decrease heart rate, i.e. ES at low temperature or amiodarone, respectively. As in the previous study utilizing adrenergic and cholinergic stimulation [7], the change in contraction rate in rat heart cell cultures was associated with changes in the density of $\mathrm{A}_{1}$ adenosine receptors.

\section{MATERIALS AND METHODS}

\section{Preparation of Heart Cell Cultures}

Rat hearts (1-2 days old) were removed under sterile conditions and washed three times in phosphate-buffered saline (PBS) to remove excess blood cells. The hearts were minced to small fragments and then gently agitated at $25^{\circ} \mathrm{C}$ for a few cycles of 10 min each in a solution of the proteolytic enzyme mixture RDB (Biological Institute, Ness-Ziona, Israel, diluted 1:50 in PBS), prepared from a fig tree extract, as described previously [7, 8, 10]. Following agitation the suspension was centrifugated at $500 \times g$ for $5 \mathrm{~min}$, the supernatant phase was discarded, and the cells were resuspended in Dulbecco's Modified Eagle Medium (DMEM, Biological Industries, Kibbutz Beit Haemek, Israel) containing high glucose (5 $\mathrm{mg} / \mathrm{mL}$ ) and supplemented with $10 \%$ heat-inactivated horse serum (Biolab, Jerusalem, Israel) and 2\% chick embryo extract. The suspension of cells was diluted to $1.0 \times 10^{6}$ cell $/ \mathrm{mL}$ with the same medium, and aliquots of $1.5 \mathrm{~mL}$ were placed in $35 \mathrm{~mm}$ collagengelatin-coated plastic culture dishes. Cultures were incubated in a humidified atmosphere of $5 \% \mathrm{CO}_{2}, 95 \%$ air at $37^{\circ} \mathrm{C}$. The incubated cells were washed well $24 \mathrm{hr}$ after plating to remove unattached cells. Confluent monolayers, which exhibit spontaneous contractions, developed in culture within 2 days. The growth medium was replaced every 3-4 days.

\section{Materials}

Amiodarone hydrochloride (Sigma, St. Louis, MO) was dissolved in $\mathrm{H}_{2} \mathrm{O}$ at $60^{\circ} \mathrm{C}$ to $1 \mathrm{mM}$, and applied to the cell cultures to final concentration of $10 \mu \mathrm{M}$. CPX was purchased from RBI (Natick, MA). $\left[{ }^{3} \mathrm{H}\right]$ CPX was obtained from Dupont NEN (Boston, MA).

Radioligand binding studies were performed as previously described [7, 15]. Intact cells were incubated at room temperature $\left(23-25^{\circ} \mathrm{C}\right)$ for $60 \mathrm{~min}$, with various concentrations of $\left[{ }^{3} \mathrm{H}\right] \mathrm{CPX}, 1 \mu \mathrm{M}$ dipyridamole, $2 \mathrm{U} / \mathrm{mL}$ adenosine deaminase in PBS, $\mathrm{pH}$ 7.4. Incubation was stopped by quickly rinsing the cells $5 \times$ with cold $\left(4-8^{\circ} \mathrm{C}\right) \mathrm{PBS}$. The cells were solubilized with $0.2 \mathrm{~mL}$ of $0.5 \mathrm{~N} \mathrm{NaOH}$, and the solution was neutralized upon addition of $0.1 \mathrm{~mL} 2 \mathrm{~N}$ Tris-HCl, $\mathrm{pH}$ 3.7. After the addition of $3 \mathrm{~mL}$ of scintillation fluid, radioactivity was 
determined using a $\beta$ counter. Nonspecific binding of $\left[{ }^{3} \mathrm{H}\right] \mathrm{CPX}$ was defined in the presence of theophylline $(5 \mathrm{mM})$. Specific binding of $\left[{ }^{3} \mathrm{H}\right] \mathrm{CPX}$ was calculated as the total radioactivity bound minus the nonspecific binding (less than $20 \%$ ).

\section{Measurement of Contractility}

Changes in the contractile state of individual cells in the monolayer cardiocytes were performed by using an optical video system. The cells were viewed with $20 \times$ objective and the image monitored by a television camera connected to a video motion detector that followed cell movements.

\section{Protein content}

Protein determination was performed following washing of the cells with PBS ( $2 x)$ according to the method of Bradford [16], using bovine serum albumin as a standard.

\section{Creatine Kinase (CK) and Lactate Dehydrogenase (LDH) Activity}

The cardiomyocytes were washed with cold PBS $(2 x)$, and the cells were homogenized in the same buffer. CK and LDH activities were determined using CK and LDH-L kits (Sigma, St. Louis, MO) and the product of the enzyme was measured spectrometrically at $23-25^{\circ} \mathrm{C}$ at a wavelength of $340 \mathrm{~nm}$.

\section{Effect of Electrical Stimulation (ES)}

Cardiomyocytes grown for 4 days in culture in a $35 \mathrm{~mm}$ dish at $37^{\circ} \mathrm{C}$ were transferred to a temperature of $25^{\circ} \mathrm{C}$ for 3 days prior to application of $\mathrm{ES}$, to reduce the rate of spontaneous contractions. ES of heart cells was carried out by placing in the culture medium a pair of platinum electrodes fastened to a cover glass to keep them separated by a distance of $25 \mathrm{~mm}$ [12]. Pulses of $20 \mathrm{~V}$ of a duration of $1 \mathrm{msec}$ each were applied at a frequency of $4 \mathrm{~Hz}$. After $\mathrm{ES}$, the density of $\mathrm{A}_{1}$ adenosine receptors was determined using radioligand saturation binding.

\section{Statistics}

The data are presented as mean \pm SE. Statistical significance was estimated using the Student's $t$-test, with a $P$ value of less than 0.05 considered significant. Binding data were represented graphically using Scatchard plots, and the parameters of $K_{\mathrm{d}}$ and $B_{\max }$ were calculated using the LIGAND program.

\section{RESULTS}

\section{Effect of Amiodarone on $\left[{ }^{3} \mathrm{H}\right] \mathrm{CPX}$ Binding}

Myocardial cells (5 days old) were treated with $10 \mu \mathrm{M}$ amiodarone at $37^{\circ} \mathrm{C}$ for 4 days. Scatchard analysis of $\left[{ }^{3} \mathrm{H}\right] \mathrm{CPX}$ binding indicates that the maximum binding sites were 24.7 $\pm 0.4 \mathrm{fmol} / \mathrm{dish}$ in untreated cells and $20.09 \pm 0.30 \mathrm{fmol} / \mathrm{dish}$ in amiodarone treated cells (Fig. 1). The $K_{\mathrm{d}}$ for $\left[{ }^{3} \mathrm{H}\right] \mathrm{CPX}$ binding was $0.22 \pm 0.1 \mathrm{nM}$ and $0.28 \pm 0.09 \mathrm{nM}$ for the control group and amiodarone treated group, respectively. Thus, a $19 \%$ decrease in the density $\left(B_{\max }\right)$ of $\left[{ }^{3} \mathrm{H}\right] \mathrm{CPX}$ binding was observed following 4 days of amiodarone treatment in 
comparison to control, while the affinity for the radioligand was nearly unchanged. The onset of this change in receptor density was delayed, because no significant change was observed in the level of binding to $A_{1}$ adenosine receptors during the initial 1-24 $\mathrm{hr}$ of treatment (data not shown).

The dose dependence of the depressant effect of amiodarone at $37^{\circ} \mathrm{C}$ on heart rate is shown in Fig. 2. Amiodarone $(0.1-30 \mu \mathrm{M})$ inhibited (15-80\%) heart rate following 24, 48, and 72 $\mathrm{hr}$. There were no significant differences in protein content, CK activity and cell number, between control and amiodarone-treated cells (Table 1).

\section{Effect of Electrical Stimulation (ES) and Temperature on $\left[{ }^{3} \mathrm{H}\right] \mathrm{CPX}$ Binding}

To decrease the spontaneous contractions the cardiac cells were transferred from 37 to $25^{\circ} \mathrm{C}$, as described in Materials and Methods, prior to electrical stimulation. Scatchard analysis showed an increase of $A_{1}$ adenosine receptors from $4.14 \pm 0.4$ to $11.69 \pm 2.1 \mathrm{fmol} / \mathrm{dish}$ following $36 \mathrm{hr}$ of electrical stimulation, without a significant change in the affinity of $\left[{ }^{3} \mathrm{H}\right] \mathrm{CPX}$ (Fig. 3). There were no significant differences in protein content, cell number, CK, and LDH activity between control and ES treated cells (Table 2). Four-day-old cultures that had been transferred from 37 to $25^{\circ} \mathrm{C}$ for 4 days, displayed contractility reduced from $96 \pm 8$ to $36 \pm 6$ beats $/ \mathrm{min}$. Lowering the temperature also reduced the density of adenosine receptors from $24.1 \pm 1.2 \mathrm{fmol} / \mathrm{dish}$ at $37^{\circ} \mathrm{C}$ to $3.4 \pm 0.3$ and $7.4 \pm 04 \mathrm{fmol} / \mathrm{dish}$ at 25 and $30^{\circ} \mathrm{C}$, respectively (Fig. 4). Following this treatment, cell number, protein content, $\mathrm{CK}$, and LDH activity remained essentially unchanged (Table 2).

\section{DISCUSSION}

The in vitro model of the neonatal cultured rat heart has enabled us to examine the direct effects of ES, amiodarone, and temperature changes on myocytes, particularly with respect to regulation of $A_{1}$ adenosine receptors.

Amiodarone acts as a class III antiarrhythmic drug $[17,18]$, and has been shown to inhibit ATP-sensitive potassium channels [19], to interact with myocardial $\mathrm{Na}^{+} \mathrm{K}^{+}$-ATPase in guinea pig microsomal preparations [20] and to protect the ischemic rat heart by inhibiting oxidative phosphorylation [21]. Intramuscular or intravenous amiodarone treatment has been used in controlling tachyarryhthmia in children [22] and young adults [23], and results in sustained bradycardia clinically. The mechanism of action of amiodarone in reducing heart rate is unclear. One possibility is antagonism of catecholamines acting at $\beta$ - adrenergic receptors $[10,11]$. Other possibilities are uncoupling of electrical activity and contraction (unpublished), or inhibition of $\mathrm{Ca}^{2+}$ uptake to the SR [24].

The present results confirm that amiodarone depresses the rate of contraction of cardiac myocytes in primary culture. Furthermore, amiodarone specifically attenuated the density of radioligand binding to $\mathrm{A}_{1}$ adenosine receptors by $19 \%$ without changing the $K_{\mathrm{d}}$ value. The findings that amiodarone decreased contractility supports the idea that amiodarone-treated cardiocytes decrease their sensitivity to $\mathrm{A}_{1}$ adenosine agonist. Indeed, increase in the $\mathrm{EC}_{50}$ of the $\mathrm{A}_{1}$ adenosine receptor agonist $R$-PIA in depressing spontaneous contractility in cardiac cell cultures following chronic amiodarone treatment was observed (data not shown). 
This finding may have clinical implications for further research to consider the effect of modulating adenosine receptors in antiarrhythmic therapy [25], perhaps using a combination of amiodarone and an adenosine receptor ligand $[1,26]$.

Amiodarone was first developed for use as an antiangina agent (for review, see [17], whereas adenosine injections have been reported to be accompanied by angina pain [27]. We raise the possibility here that amiodarone, by reducing the level of adenosine receptors, may reduce the susceptibility to adenosine-induced angina pain.

Electrical stimulation has been shown to cause membrane depolarization, biochemical, and physiological changes in the cells [28, 29]. In our myocyte cultures, CK, and LDH activity, protein content, and cell number remained nearly unchanged following ES. However, $36 \mathrm{hr}$ of electrical stimulation, caused $185 \%$ elevation in $\mathrm{A}_{1}$ adenosine receptors with no change in the affinity. This increase is probably a result of increased receptor synthesis because the protein synthesis inhibitor cycloheximide $(5 \mu \mathrm{g} / \mathrm{mL})$, prevented elevation of the level of adenosine receptors elicited by ES (data not shown). This increase also indicates that the $\mathrm{A}_{1}$ adenosine receptors become a compensation under such stress conditions of excessive contractions, as chronic treatment with amiodarone caused down-regulation of $\beta$-adrenergic receptors [11]. The elevation in $A_{1}$ adenosine receptors probably increases cardiac sensitivity to adenosine and indicates by which mechanism the heart cells may adapt to electrical stimulation stress. Further support for this mechanism of adaptation to stress was demonstrated by the effect of thyroid hormones and catecholamines that accelerated heart rate and also upregulated the $\mathrm{A}_{1}$ adenosine receptor $[7,15]$.

The important role of the $\mathrm{A}_{1}$ adenosine receptor and not $\mathrm{A}_{2}$ receptors in relation to heart contractility was reported for electrically stimulated cardiocytes that were acutely treated with $R$-PIA [30, 31]. In those cells $R$-PIA decreased contractility, while CPX, a selective $\mathrm{A}_{1}$ adenosine antagonist, antagonized the effect of $R$-PIA on contractile response. In the present study, the decrease in the level of $A_{1}$ adenosine receptors following amiodarone and low temperature treatment and the elevation of $A_{1}$ receptors following ES, suggests that the level of $\mathrm{A}_{1}$ adenosine receptors is regulated by heart contractility and environmental conditions as a mechanism to restore normal heart rate.

\title{
Acknowledgments
}

We thank A. Isaac and T. Zinman for their valuable technical assistance and to A. Goldreich for typing the manuscript. This research is supported by Grant 93-22 from the United States-lsrael Binational Science Foundation (BSF), Jerusalem, Israel. This work was carried out in partial fulfillment of the requirements for a Ph.D. degree for D. El-Ani.

\author{
Abbreviations \\ CK creatine kinase \\ CPX 8-cyclopentyl-1,3-dipropyl- xanthine \\ ES electric stimulation \\ LDH lactate dehydrogenase
}


PBS phosphate-buffered saline

SA sinoatrial

\section{References}

1. Manz M, Luderitz B. Supraventricular tachycardia and pre-excitation syndromes: Pharmacological therapy. Eur Heart J. 1993; 14:91-98. [PubMed: 8223763]

2. Honerjager P, Schmidt G. Pharmacology of modern anti-arrhythmia drugs in therapy of supraventricular tachycardia. Z Gesmate Inn Med. 1993; 48:425-429.

3. Kowey PR, Marinchak RA, Rials SJ, Rubin AM, Smith L. Electrophysiologic testing in patients who respond acutely to intravenous amiodarone for incessant ventricular tachyarrhythmias. Am Heart J. 1993; 125:1628-1632. [PubMed: 8498304]

4. Bartlett TQ, Friedman PL. Current management of the Wolff-Parkinson-White syndrome. J Cardiovasc Surg. 1993; 8:503-515.

5. Murthy VS, Hwang TF. Antiarrhythmic drugs and the modulation of autonomic control of heart rate in rabbits. Fed Proc. 1986; 45:2186-2190. [PubMed: 3013694]

6. Belardinelli L, Shryock JC, Song Y, Wang D, Srinivas M. Ionic basis of the electrophysiological actions of adenosine on cardiomyocytes. FASEB J. 1995; 9:359-365. [PubMed: 7896004]

7. El-Ani D, Jacobson KA, Shainberg A. Characterization of adenosine receptors in intact cultured heart cells. Biochem Pharmacol. 1994; 48:727-735. [PubMed: 8080445]

8. Brik H, Shainberg A. Thyroxine induces transition of red towards white muscle in cultured heart cells. Basic Res Cardiol. 1990; 85:237-246. [PubMed: 2166497]

9. Venkatesh N, Padbury JF, Singh BN. Effects of amiodarone and desethylamiodarone on rabbit myocardial $\beta$-adrenoceptors and serum thyroid hormones-absence of relationship to serum and myocardial drug concentrations. J Cardiovasc Pharmacol. 1986; 8:989-997. [PubMed: 2429101]

10. Disatnik MH, Shainberg A. Regulation of $\beta$-adrenoceptors by thyroid hormone and amiodarone in rat myocardiac cells in culture. Biochem Pharmacol. 1991; 41:1039-1044. [PubMed: 1672592]

11. Bjomerheim R, Froysaker T, Hansson V. Effects of chronic amiodarone treatment on human myocardial beta adenoceptor density and adenylate cyclase response. Cardiovasc Res. 1991; 25:503-509. [PubMed: 1653643]

12. Shainberg A, Burstein M. Decrease of acetylcholine receptor synthesis in muscle cultures by electrical stimulations. Nature. 1976; 264:368-369. [PubMed: 1004561]

13. Freud-Silverberg M, Shainberg A. Electric stimulation regulates the level of Ca-channels in chick muscle culture. Neurosci Lett. 1993; 151:104-106. [PubMed: 8385756]

14. Waisberg M, Shainberg A. Characterization of muscarinic cholinergic receptors in intact myocardial cells in vitro. Biochem Pharmacol. 1992; 43:2327-2334. [PubMed: 1610397]

15. El-Ani, D., Jacobson, KA., Shainberg, A. Regulation of adenosine receptors in cultured heart cells. In: Siderman, S., Beyar, R., editors. Molecular and Subcellular Cardiology: Effects on Structure and Function. Plenum Press; New York: 1995. p. 205-215.

16. Bradford MM. A rapid and sensitive method for the quantitation of microgram quantities of protein utilizing the principle of protein dye binding. Anal Biochem. 1976; 72:248-254. [PubMed: 942051]

17. Rotmensch HH, Belhassen B. Amiodarone in the management of cardiac arrhythmias: Current concepts. Cardiovasc Pharmacol. 1988; 72:321-358.

18. Brentano FC. Rate-dependence of class III actions in the heart. Clin Pharmacol. 1993; 7:51-59.

19. Haworth RA. Goknur AB and Berkoff HA, Inhibition of ATP-sensitive potassium channels of adult rat heart cells by antiarrythmic drugs. Circ Res. 1989; 65:1157-1160. [PubMed: 2791223]

20. Dzimiri N, Almotrefi AA. Amiodarone: Biochemical evidence for its interaction with myocardial $\mathrm{Na}^{+} \mathrm{K}^{+}$-ATPase in guinea pig microsomal preparations. Biochem Pharmacol. 1991; 41:470-472. [PubMed: 1847288] 
21. Nokin P, Jungbluth L, Mouton J. Protective effects of amiodarone pretreatment on mitochondrial function and high energy phosphates in ischemic rat heart. J Mol Cell Cardiol. 1987; 19:603-614. [PubMed: 3625789]

22. Perry JC. Intravenous amiodarone for life-threatening tachyarrhythmia in children and young adults. J Am Coll Cardiol. 1993; 22:8-95. [PubMed: 8509567]

23. Wynnewood PA. Electrophysiologic testing in patients who respond to intravenous amiodarone for incessant ventricular tachyarrhythmias. Am Heart J. 1993; 125:1628-1632. [PubMed: 8498304]

24. Weinstein L, Brik H, Rotmench HH, Shainberg A. Characterization of sarcoplasmic reticulum in skinned heart muscle cultures. J Cell Physiol. 1991; 148:124-132. [PubMed: 1860892]

25. Pelleg A, Belardinelli L. Cardiac electrophysiology of adenosine: Basic and clinical aspects. Cardiol Res. 1993; 27:54-61.

26. Grauer K, Cavallaro D, Gums J. New developments in cardiopulmonary resuscitation. Am Fam Physician. 1991; 43:832-844. [PubMed: 2000728]

27. Sylven C, Beermann B, Jonzon B, Brandt R. Angina pectoris-like pain provoked by intravenous adenosine in healthy volunteers. Br Med J. 1986; 293:227-230. [PubMed: 3089465]

28. Luther PW, Peng HB, Lin JJC. Changes in cell shape and actin distribution induced by constant electric fields. Nature. 1983; 303:61-64. [PubMed: 6682488]

29. Robinson HR. The response of cells to electrical fields: A review. J Cell Biol. 1985; 101:20232027. [PubMed: 3905820]

30. Behnke N, Muller W, Neumann J, Schmitz W, Scholz H, Stein B. Differential antagonism by 1,3dipropylxanthine-8- cyclopentylxanthine and 9-chloro-2-2-(-2-furanyl)-5,6-dihydro-1,2,4triazolo(1,5-C) quinazolin-5-imine of the effects of adenosine derivatives in the presence of isoprenaline on contractile response and cAMP content in cardiomyocytes. Evidence for the coexistence of $A_{1}$ and $A_{2}$ adenosine receptors on cardiomyocytes. J Pharmacol Exp Ther. 1990; 254:1017-1023. [PubMed: 2168481]

31. Stein B, Schmitz W, Scholz H, Seeland C. Pharmacological characterization of $\mathrm{A}_{2}$-adenosine receptors in guinea pig ventricular cardiomyocytes. J Mol Cell Cardiol. 1994; 26:403-414. [PubMed: 8028023] 


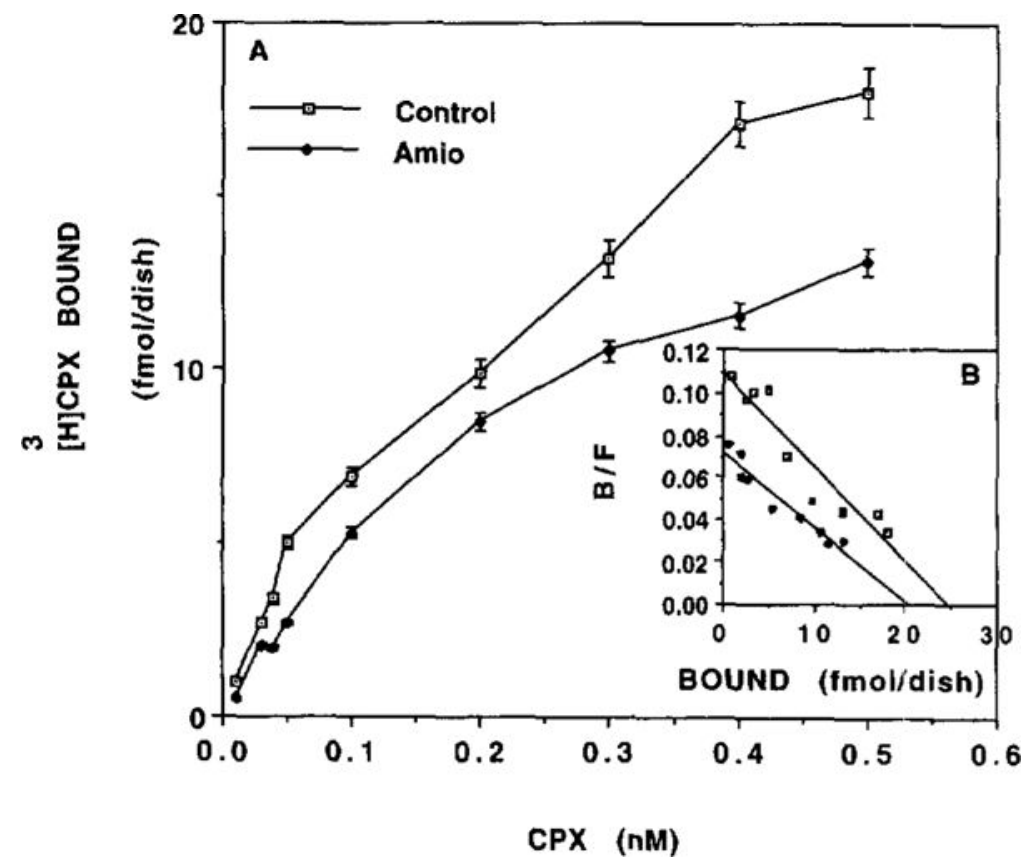

FIG. 1.

Effect of amiodarone on $\left[{ }^{3} \mathrm{H}\right] \mathrm{CPX}$ binding to intact myocyte cultures. Five-day-old cardiocytes were treated with $10 \mu \mathrm{M}$ amiodarone at $37^{\circ} \mathrm{C}$ for 4 days, and specific binding of $\left[{ }^{3} \mathrm{H}\right] \mathrm{CPX}$ was determined. (A) Saturation of binding to $\mathrm{A}_{1}$ receptors in control and treated cultures. (B) Scatchard transformation of data from Fig. 1A. $K_{\mathrm{d}}=0.22 \pm 0.1$ and $0.28 \pm 0.09$ $\mathrm{nM}$ and $B_{\max }=24.7 \pm 0.4$ and $20.09 \pm 0.30 \mathrm{fmol} / \mathrm{dish}$ were calculated for the control and amiodarone treated cells, respectively. Each point is the mean $( \pm \mathrm{SE})$ of triplicate determinations of a representative experiment out of three experiments that gave similar results. 


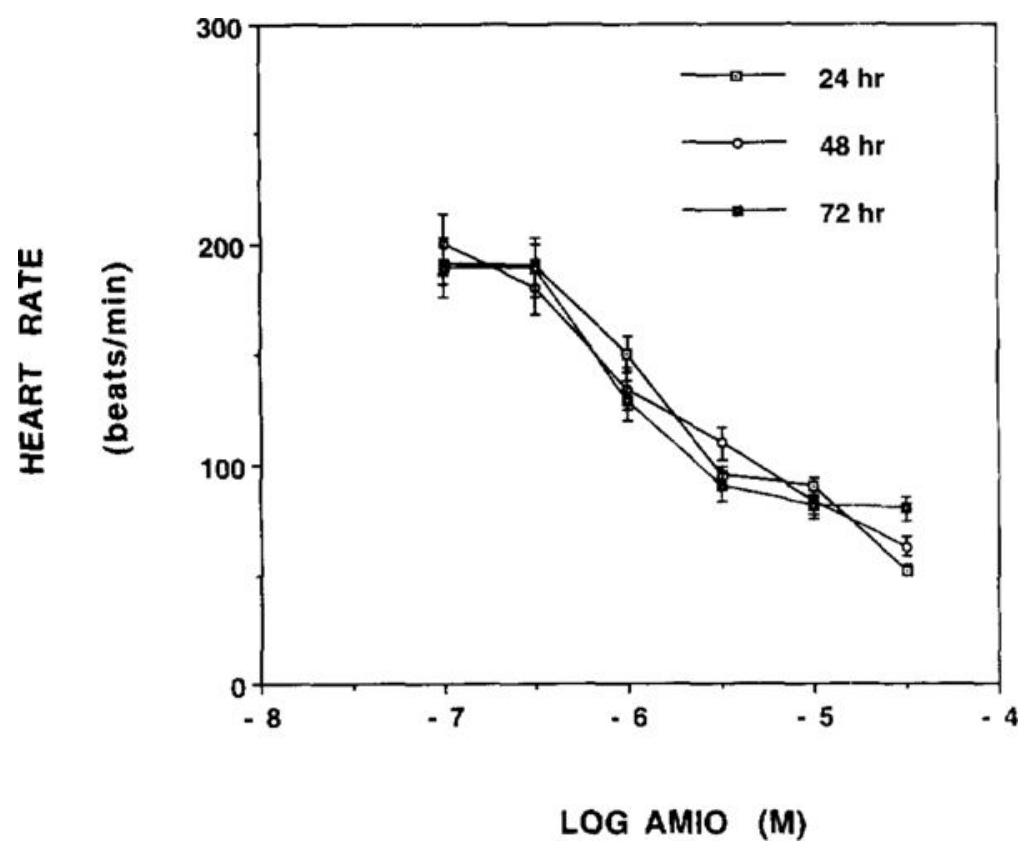

FIG. 2.

Dose response of amiodarone on heart rate in myocyte cultures. Five-day-old cardiocytes were treated at $37^{\circ} \mathrm{C}$ with different concentrations of amiodarone. Contraction rate was determined at the indicated times. Each point represents the mean $( \pm \mathrm{SE})$ of triplicate determinations of a representative experiment out of three experiments that gave similar results. 


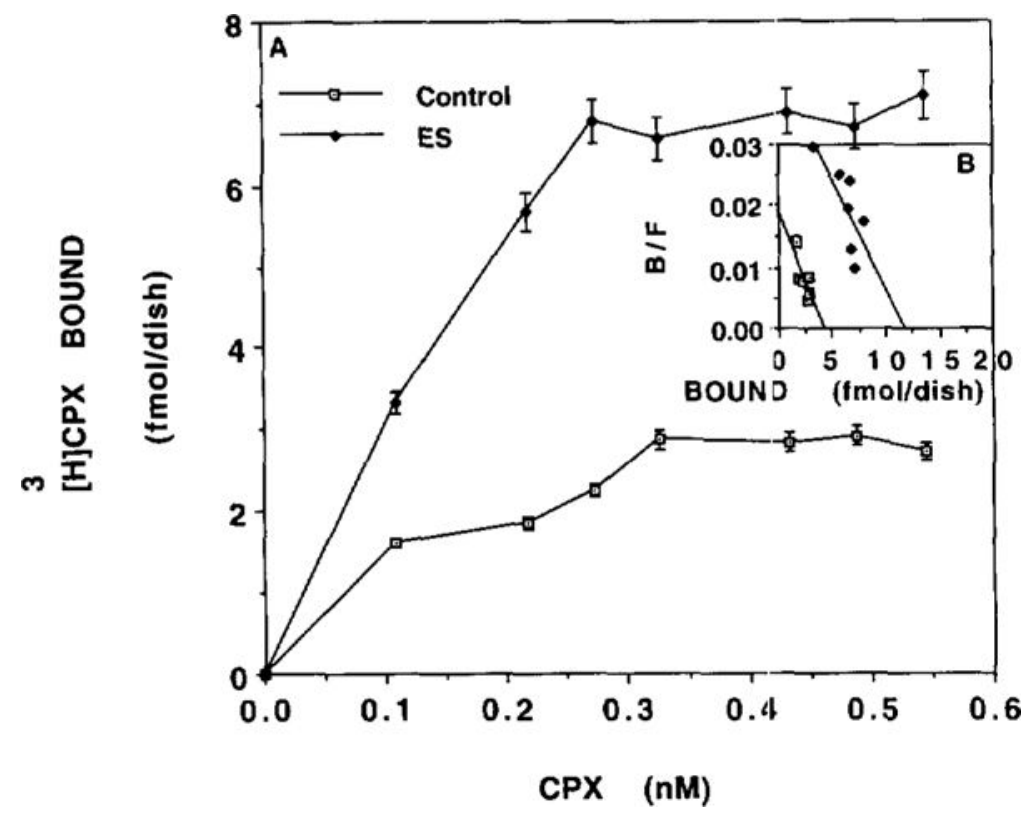

FIG. 3.

The effect of ES on $\left[{ }^{3} \mathrm{H}\right] \mathrm{CPX}$ binding to intact myocyte cultures. Four-day-old cardiocytes were transferred from 37 to $25^{\circ} \mathrm{C}$ for 3 days. The cells were then electrically stimulated for $36 \mathrm{hr}$ at $4 \mathrm{~Hz}$, and specific $\left[{ }^{3} \mathrm{H}\right] \mathrm{CPX}$ binding was determined. (A) Saturation of binding to $\mathrm{A}_{1}$ receptors in control and treated cultures. (B) Scatchard transformation of data from Fig. 3A. $K_{\mathrm{d}}=0.22$ and $0.28 \mathrm{nM}$ and $B_{\max }=4.1 \pm 0.4$ and $11.69 \pm 2.1 \mathrm{fmol} /$ dish were calculated for the control and electrically stimulated cells, respectively. Each point is the mean $( \pm \mathrm{SE})$ of triplicate determinations of a representative experiment out of three experiments that gave similar results. 


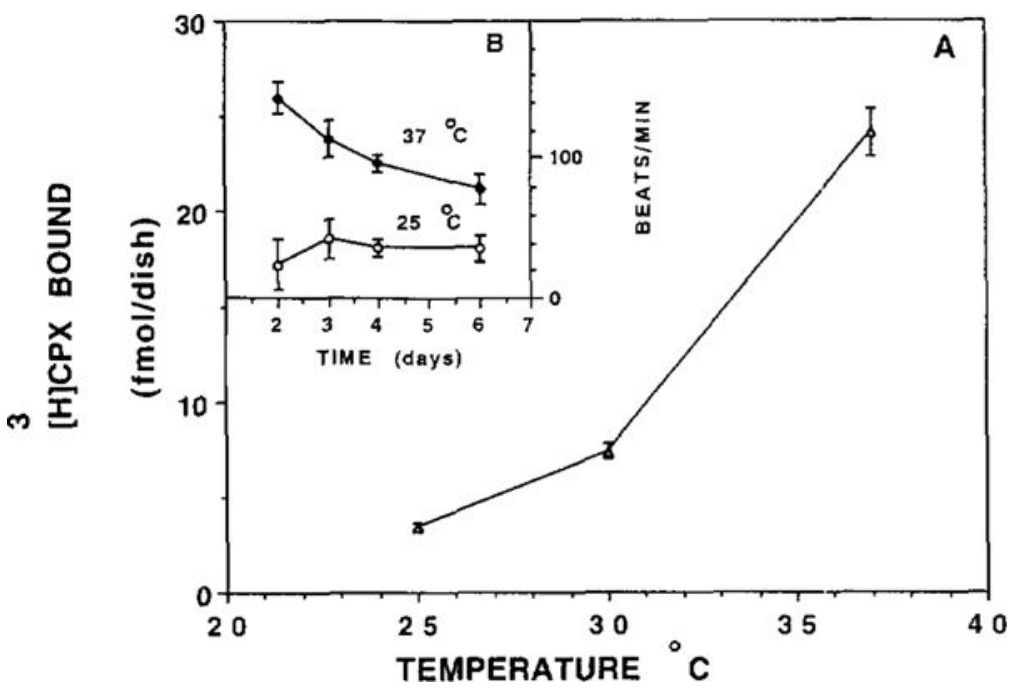

FIG. 4.

The effect of temperature on $\left[{ }^{3} \mathrm{H}\right] \mathrm{CPX}$ binding and heart rate. Four-day-old cardiocytes were transferred from $37^{\circ} \mathrm{C}$ to either $25^{\circ} \mathrm{C}$ or $30^{\circ} \mathrm{C}$. Specific $\left[{ }^{3} \mathrm{H}\right] \mathrm{CPX}$ binding to intact cells as a function of temperature following 4 days of treatment (A) and heart rate at the indicated times (B) were measured. Each point is the mean $( \pm \mathrm{SE})$ of triplicate determinations of a representative experiment out of three experiments that gave similar results. 


\section{TABLE 1}

Summary of the effects of amiodarone on rat cardiac cells in primary culture

\begin{tabular}{lccc}
\hline & Control & Amiodarone & $\boldsymbol{P}$ \\
\hline CK (U/dish) & $0.40 \pm 0.01$ & $0.42 \pm 0.1$ & NS \\
Protein (mg/dish) & $0.89 \pm 0.10$ & $0.99 \pm 0.08$ & NS \\
Cell number $\left(\times 10^{4}\right)$ & $121 \pm 20$ & $133 \pm 25$ & NS \\
Rate of Contractions (beats/min) & $179 \pm 20$ & $72 \pm 28$ & $<0.05$ \\
Adenosine receptors (fmol/dish) & $24.7 \pm 0.4$ & $20.09 \pm 0.30$ & $<0.05$ \\
\hline
\end{tabular}

Five-day-old cardiocytes were treated with $10 \mu \mathrm{M}$ amiodarone at $37^{\circ} \mathrm{C}$ for 4 days. The indicated data were measured on separate dishes according to Materials and Methods. The results are expressed as means $\pm \mathrm{SE}$ of triplicate determinations of a representative experiment out of three experiments that gave similar results.

NS, not significant. 


\section{TABLE 2}

Summary of the effects of ES on rat cardiac cells in primary culture

\begin{tabular}{lccc}
\hline & Control & ES & $\boldsymbol{P}$ \\
\hline CK (U/dish) & $0.50 \pm 0.09$ & $0.45 \pm 0.15$ & NS \\
LDH (U/dish) & $0.69 \pm 0.13$ & $0.60 \pm 0.1$ & NS \\
Protein (mg/dish) & $0.98 \pm 0.09$ & $1.1 \pm 0.12$ & NS \\
Adenosine receptors (fmol/dish) & $4.14 \pm 0.4$ & $11.69 \pm 2.1$ & $<0.05$ \\
\hline
\end{tabular}

Four-day-old cardiocytes were transferred from 37 to $25^{\circ} \mathrm{C}$ for 3 days and then were electrically stimulated $(4 \mathrm{~Hz})$ as described in Materials and Methods. The results are expressed as means $\pm \mathrm{SE}$ of triplicate determinations of a representative experiment out of three experiments that gave similar results.

NS, not significant. 